\title{
Economy-wide Implications of Low Carbon Electricity Based Mass Transport in Nepal
}

\author{
Shree Raj Shakya \\ Energy Systems Planning and Analysis Unit, Centre for Energy Studies, Institute of Engineering, \\ Tribhuvan University, Nepal \\ Corresponding Email: shreerajshakya@ioe.edu.np; shreerajshakya@gmail.com
}

\begin{abstract}
Development of low carbon electricity based mass transport is considered as one of the promising options for perusing the low carbon development (LCD) path in 21 st century by the global communities. But long term economy-wide implications of such policy is very much country specifics citing their variations in the availability and tapping potential of indigenous clean energy resources, access to the clean technologies, affordability and acceptability of such technologies, and so on. This paper studies the economy-wide consequences of introducing different levels of electrified mass transport systems in Nepal on the long term basis. The study develops and uses a multi-sector, single region, recursive dynamic computable general equilibrium model of Nepal (Nepal-TRNSCGE) with technology level disaggregation in the transport and electricity sectors. The study indicates that under transport electrification scenarios consisting of $10 \%$ to $30 \%$ electrification of the transport sector as compared to the base case by 2050 , the country would benefit economically with the value of cumulative undiscounted GDP increasing in the range of $2.6 \%$ to $3.1 \%$ and the value of cumulative undiscounted equivalent variation in income (household welfare) increasing in the range of $25.3 \%$ to $147.9 \%$ during 2005 to 2050 . The policy would promote energy efficiency improvement and cleaner economic development with significant reduction in the energy intensity of GDP in the range of $3.1 \%$ to $4.1 \%$ and greenhouse gas intensity of GDP in the range of $4.7 \%$ to $7.1 \%$. This highlights the potential role of low carbon electricity based transport in achieving the LCD path in the country. Introducing foreign direct investment would further increase GDP but reduce household welfare.
\end{abstract}

Keywords: Transport electrification, low carbon development, macroeconomic effects, household welfare, energy intensity, greenhouse gas, CGE modeling, developing country, Nepal

\section{Introduction}

An ever increasing concern for the escalating effects of global climate change has brought together the national and global policy makers to the consensus that inorder to achieve meaningful reduction in greenhouse gas emissions in stipulated time frame there has to be paradigm shift from conventional carbon intensive economic development path to low carbon development (LCD) path on a long run. Since energy is the main components for economic development and also the main source of anthropogenic GHG emissions, the only way of following sustainable development of the society is through switching to the low carbon energy resources and technologies [32]. The electrification of the transport sector is considered as one of the promising options for perusing the LCD path by the global communities which emphasize the need for adaptation of the sustainable mean of economic development in $21^{\text {st }}$ century. But long term economy-wide consequences of such policy is very much country specifics citing their 
variations in the availability and tapping potential of indigenous clean energy resources, access to the clean technologies, affordability and acceptability of such technologies, and so on.

There are limited studies that focused on analysisng implications of LCD policies in Nepal using modeling approach on the long term basis [46, 47, 48] studied the implications, in terms of hydropower development, energy security, emission of local pollutants, energy system cost and employment generation, of introducing different shares of electric mass transport system and electric vehicles in the land transport service demands of Nepal during 2005 to 2050. Similarly, [46] analyze the co-benefits related to energy supply security, energy efficiency, energy system cost, employment generation and emission of local pollutants of introducing different levels of carbon tax in the country during 2005 to 2050. Shrestha and Shakya (2012) analyze the potential implications of adopting a $\mathrm{CO}_{2}$ emission reduction target policy for indigenous resource development, energy security, emission of local pollutants, energy system cost and employment generation from a longer term integrated energy sector planning perspective covering the period of 2005 to 2100 . But all of these studies used bottom-up modeling approach and did not considerd economy-wide consequences of such policies. This paper analyses the economy-wide implications in terms of change in GDP, trade of commodities, household welfare, energy and emission intensities of GDP while introducing different levels of the electrified mass transport systems and electric vehicles in Nepal on the long term basis. This study develops and uses a multi-sector, single region, recursive dynamic computable general equilibrium model of Nepal (Nepal-TRNSCGE) with technology level disaggregation in the transport and electricity sectors for analyzing the economy-wide implications of undertaking transport electrification policy.

There are few studies on macroeconomic effects of investment flow in the transport and energy sectors of developing countries. Effect of investment in energy sector in developing country context has been studied by several studies $[5,6,12,13,16,25,26,36,50]$. Kyophilavong and Toyoda (2008) and Warr (2006) have studied macroeconomic effects of investment flow in hydropower sector of Loa PDR. Macroeconomic effects of hydropower development in Paraguay has been studied by [16]. Kojo (2005) and Osmani et al. (2007) have studied macroeconomic implications of investment flow in hydropower sector of Bhutan. However, studies of [16], [25], [26], and [36] are based on partial equilibrium models. At the same time study by Warr (2006) is based on very much aggregated one consumer and two sectors (1-2-3) static general equilibrium model framework [15]. Similarly, Chuanyi et al. (2010) used static computable general equilibrium (CGE) model and [12] used recursive dynamic CGE model to analyze effect of investment increase in energy sector of Shaanxi province of China on the sectoral GDP distribution and export. Benjamin et al. (1989) used static CGE model to study impact of oil boom on the other traded and non-traded sectors of the Cameroon economy. Barry (2009) used static CGE model to investigate implication of FDI flow in the energy sector on the trade balance of Central Asia (Turkmenistan, Uzbekistan and Kazakhstan). However, these studies did not use energy as a separate factor of production and did not include disaggregated electricity sector.

Several studies have analyzed the effects on the national and regional economy due to the investment flow in the transport sector [18, 24, 49]. Siddiqui (2007) has used dynamic CGE model to study the effect of tax financed public investment in the transport service sector and transport infrastructure in Pakistan. Gilbert and Banik (2010) analysed impact of investment in international land transport infrastructure in five South Asian counrtries (India, Sri Lanka, Bangladesh, Nepal and Pakistan) using static CGE model. Similarly, [24] has analysed effects of 
investment in highway construction on the regional GDP and welfare in Korea using transport network-multiregional CGE model. These studies do not disaggregate the transport sector elaborately representing electic and non-electric modes of transportation as well as no representation of disaggregated power supply sector.

As such, there is study gap relating to the economy-wide implications of investment flow in transport and energy sectors due to transport sector electrification in the context of developing country. In case of Nepal no such studies so far has been done at present. In this context, it would be useful for policy makers in the country and abroad to get acquainted with implications of sector specific LCD options such as transport sector electrification in the context of the small economy country with large hydropower resources. The result of the study can be valuable in devising the appropriate measures to avoid or mitigate the possible negative effects of the policy considered here.

A key finding of the study indicates that Nepal would benefit from the implementation of transport sector electrification process on long run with the increase in GDP in all the transport electrification scenarios and household welfare in most of the transport electrification scenarios. Besides, transport electrification would promote energy efficiency improvement and cleaner economic development with significant reduction in the energy intensity of GDP and greenhouse gas intensity of GDP. This highlights the importance of the transport sector electrification as one of the desirable options in achieving the low carbon development path in the country. In addition, Introducing foreign direct investment would further increase GDP but would reduce household welfare.

The paper is divided into eight sections. The next section (second section) presents a brief overview of transport, energy and climate change policies of Nepal. The third section discusses the development of national CGE model of the country. Methodology is discussed in section four. Descriptions of the scenarios are presented in the fifth section. This is followed by the discussion of the macroeconomic effects of different transport electrification scenarios and effects of foreign direct investment. Finally, key findings of the study are summarized along with concluding remarks.

\section{Overview of transport, energy and climate change related policies in Nepal}

The Government of Nepal (GoN) has issued the National Transport Policy 2001/02 which emphasized the reduction of harmful environmental emissions from the transport sector by promoting hydroelectricity based transportation system throughout the country [33]. The Eighth, Ninth and Tenth Five-Year Plans of the country (covering the periods of 1992-1997, 1997-2002 and 2002-2007 respectively) gave an emphasis on the expansion of the government owned electric trolley bus service operating inside the Kathmandu valley (see [19] and [33]). However, such an expansion did not materialize and the trolley bus service became stand still by 2004. On the other hand, electric 3-wheelers operated by the private sector is still in operation inside the Kathmandu valley. Recently, the GoN has come up with the long term plan to introduce electric railway system joining east to west of the country and also connecting the major cities (Kathmandu and Pokhara) [39].

The national hydropower development policy was introduced by the GoN in 1992 which emphasized the use of hydropower to reduce fossil fuel consumption and promote conservation of environment [52]. GoN had adopted 25-year National Water Resources Strategy 2002, and 
one of its objectives was to optimize the use of indigenous hydropower resource by diversifying the use of electricity [52]. The GoN had introduced a medium term plan to develop 10,000 MW hydropower by 2020 dedicated to domestic market and export [31]. Later, it was revised to develop 25,000 MW of hydropower by 2030 and also mentioned the potential to develop up to $37,628 \mathrm{MW}$ by that year [27].

The Government of Nepal has recently introduced the Climate Change Policy 2010, which states the main objectives as (i) promotion of the use of clean and renewable energy resources in the country and (ii) adoption of climate friendly socio-economic development by following a low carbon development path [28]. It also envisages formulating the national low carbon development plan by 2013. However, the existing transport, energy and climate policy documents of the country fail to systematically analyze the interrelations among these policies and their macroeconomic consequences which the present study is focused to.

\section{Overview of Nepal-TRNSCGE Model}

There exist a number of studies based on development and analysis of CGE model in Nepal $[1,2,7,9,42,43]$. However, these studies were mostly based on analyzing implications from trade liberalization and other macroeconomic policies but not address policies related to transport, energy and environment in perticular. As such, there is a research gap in the economywide implications from the implementation of transport electrification policy using elaborate CGE framework for the country.

The CGE model of Nepal developed for this study (hereafter referred to as Nepal-TRNSCGE model) consists of several distinctive features which are not yet available in other earlier CGE model developed for the country. They are as following:

- It considers disaggregated electricity sector including hydropower and other power generation technologies (diesel-fired power plant, wood gasification combined cycle power plant and MSW-based power plant).

- The model considers disaggregated land transport sectors comprising of freight and passenger transport service sectors. Household transport demand consists of the consumption of public passenger transport service and private mode of transportations.

- It also considers energy as factor of production.

- Fossil fuels are disaggregated into gasoline, diesel, kerosene, LPG, ATF and coal in the social accounting matrix (SAM).

The Nepal-TRNSCGE is a multi-sector recursive-dynamic CGE model designed for an assessment of the effects on sectoral distribution of the GDP and household welfare due to the transport electrification policy in the country during 2005-2050. It includes four institutions, which are households, production firms, government and rest of the world (RoW). Economic behavior of households deal with maximization of their utilities under their budget constraints. The production firms maximize their profits (minimizes their costs). The model adopts a neoclassic approach with full employment of capital and labor supplied by household in the factor market. The government institution acts as the central agency which collects taxes and receives foreign transfer and it spends the collected revenue through public consumption, public investment and institutional transfer to the household. An assumption of a small open-economy is considered in the model with Nepalese economy regarded as price taker from the world 
market. The RoW acts as a foreign agent involving in the trade of commodities and institutional transfer. It is assumed that the country's economy is initially in equilibrium condition. The model is developed based on a SAM of Nepal for the year 2005 and using General Algebraic Modeling System (GAMS) programming language. It is based on relaxed mixed integer nonlinear programming and uses GAMS/PATHNLP solver [40].

The macroeconomic implications of transport electrification policy is analyzed by exogenously introducing the individual electric mass transport system and electric vehicles technology based demands in the transport sectors and household consumption with their share in the total land transport demand estimated based on the technology specific shares generated by the NepalMARKAL model under different transport electrification scenarios (see [47]). The effect of foreign direct investment (FDI) is studied by introducing foreign owned capital to cover exogenously specified shares of the additional investment required in the transport and electricity sectors under different transport electrification scenarios as compared to the base case. The detail equations used in the Nepal-TRNSCGE model is available in [45].

\subsection{Classification of production sectors and commodities}

The study develops the SAM of Nepal for 2005 mostly based on the input-output table representing 57x57 commodities for 2000/01 developed by [21]. The Nepal-TRNSCGE model considers aggregated 12x12 activities based production sectors as shown in Table 1 in order to highlight main features involved in the policy issues, availability of data and need for easing the computing time and cost.

The aggregation of the production sectors is based on the major economic sectors considered in the economic survey report by [30]. The desegregations in the transport and energy sectors are done to capture the issues relating to implications of transport electrification policy. There are 5 non-energy commodity production sectors, 3 energy commodity production sectors and 4 transport service sectors as shown in Table 1. The non-energy sectors consist of agriculture and forestry, manufacturing, motor vehicles, commercial and other public services. Three energy good sectors consist of electricity, lignite and fuelwood. The electricity sector includes four power generation technologies; hydropower, diesel-fired power plant, wood gasification combined cycle power plant and MSW-based power plant as subsectors to generate electricity commodity. Transport sectors consist of land freight, land passenger, air transport sectors and other transport. The land freight and land passenger transport sectors are disaggregated into road transport, rail transport and ropeway transport subsectors. The road transport sector is further disaggregated to the individual technology level as discussed in following sections.

Altogether 12 commodities are produced from domestic production sectors and 6 fossil fuels are treated as separate imported commodities. The imported fossil fuels consisting of diesel, gasoline, kerosene, LPG, Aviation Turbine Fuel (ATF) and industrial grade coal are the major energy based imported intermediate input to the production sectors and main consumption commodities of the households. As Nepal is totally dependent on import for fossil fuels, incorporation of these in the SAM is very important for actual representation of input/output dynamics, energy intensity and greenhouse gas intensity of the economy. 
Table 1: Production sectors and produced/imported commodities in the model

\begin{tabular}{|c|c|c|c|}
\hline & \multicolumn{2}{|c|}{ Production Sectors } & \multirow{2}{*}{$\begin{array}{l}\text { Produced/Imported Commodities } \\
\text { Agriculture and Forestry products }\end{array}$} \\
\hline 1 & Non-Energy & Agriculture and Forestry & \\
\hline 2 & & Manufacturing & Manufacturing products \\
\hline 3 & & Motor Vehicles & Motor Vehicles \\
\hline 4 & & Commercial & Commercial service \\
\hline 5 & & Public service & Public service \\
\hline 6 & Energy & $\begin{array}{l}\text { Electricity generation: hydropower, } \\
\text { diesel generator, thermal-fuel wood } \\
\text { based, and MSW-based technologies }\end{array}$ & Electricity \\
\hline 7 & & Lignite & Lignite \\
\hline 8 & & Fuel wood & Fuel wood \\
\hline 9 & Transport & $\begin{array}{l}\text { Land freight transport: road (further } \\
\text { sub divided into different modes and } \\
\text { technologies), rail and ropeway } \\
\text { transport services }\end{array}$ & Land freight transport service \\
\hline 10 & & $\begin{array}{l}\text { Land passenger transport: road (further } \\
\text { sub divided into different modes and } \\
\text { technologies), rail and ropeway } \\
\text { transport services }\end{array}$ & Land passenger transport service \\
\hline 11 & & Air transport & Air transport service \\
\hline \multirow[t]{7}{*}{12} & & Other transport & $\begin{array}{l}\text { Other transport service includes } \\
\text { heavy duty vehicles and others. }\end{array}$ \\
\hline & & Imported fossil fuels & Diesel \\
\hline & & & Gasoline \\
\hline & & & Kerosene \\
\hline & & & Liquefied Petroleum Gas (LPG) \\
\hline & & & Air Turbine Fuel (ATF) \\
\hline & & & Industrial grade coal \\
\hline
\end{tabular}

\subsection{Structure of main production sectors}

Nepal-TRNSCGE model consists of 12 aggregated production sectors producing one commodity per sector. The production behavior of each production sector is represented by nested production function structure composed of six-step hierarchical profit optimization process (Figure 1). Similar nested structure is used by [37], [38], [44], [23], [51], and [14]. The producing firms minimize their costs of production for each level of the output. Firms have to compete among themselves for using the common production factors consisting of capital and labor. The firms try to minimize their production costs at the given production technologies under the constant returns to scale. 


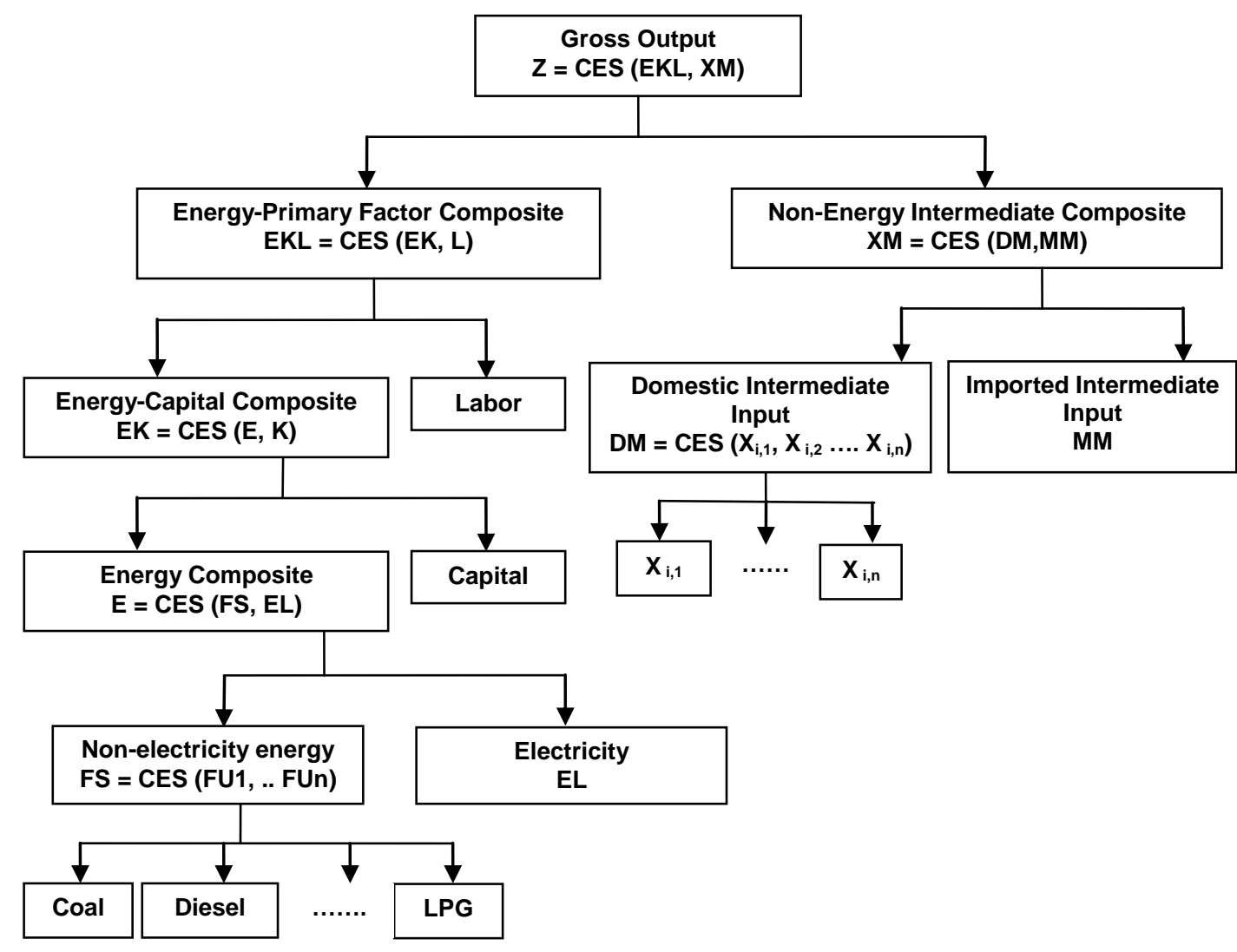

Figure 1: Nested production structure

At the upper nest of a six-layer production structure, the gross domestic output excluding production tax $\left(\mathrm{Z}_{\mathrm{i}}\right)$ from the production sector (i) (except for electricity sector and freight and passenger land transport sectors) is from the aggregate energy-capital-labor primary factor $\left(\mathrm{EKL}_{\mathrm{i}}\right)$ and aggregate non-energy intermediate inputs bundle $\left(\mathrm{XM}_{\mathrm{i}}\right)$ with the assumption of a constant elasticity of substitution (CES). At the second level, the producer optimizes its level of aggregate energy-capital input $\left(\mathrm{EK}_{\mathrm{i}}\right)$ and labor input $\left(\mathrm{L}_{\mathrm{i}}\right)$ under the nested CES production function. Similarly aggregate non-energy intermediate inputs bundle $\left(\mathrm{XM}_{\mathrm{i}}\right)$ consists of nested CES production function of domestic non-energy intermediate inputs $\left(\mathrm{DM}_{\mathrm{i}}\right)$ and imported (noncompetitive) non-energy intermediate inputs (MM) under the same level (it is also adopted by Acharya (2010) and Burfisher (2011)). At the third level, energy composite and capital is nested according to the CES production function. Also, the producer allocates individual domestic nonenergy intermediate inputs $\left(\mathrm{M}_{\mathrm{i}, \mathrm{c}}\right)$ according to the CES production function under the same level. At the fourth level, the producer selects the optimal level of electricity $\left(\mathrm{EL}_{\mathrm{i}}\right)$ and non-electric fuels $\left(\mathrm{FS}_{\mathrm{i}}\right)$ according to the CES production function. The producer allocates the non-electric energy bundle (i.e., fuel wood, coal, LPG, gasoline, diesel, kerosene) by the CES production function at the fifth level.

Further, at the lowest level, demand of the domestic good and service $\left(\mathrm{X}_{\mathrm{i}, \mathrm{c}}\right)$ is supplied by the domestic producuction $\left(\mathrm{XDD}_{\mathrm{c}}\right)$ and import $\left(\mathrm{IMP}_{\mathrm{c}}\right)$ nested under the CES Armington's specification (i.e., assumption of imperfect substitutability between domestic and imported 
goods [4]) as shown in Figure 6. In case of non-competitive imported fuel and intermediate input commodities they are supplied from import only.

\subsection{Structure of disaggregated electricity generation sector}

The formulation of production module for electricity generation sector is disaggregated to represent individual technology used for electricity generation (Figure 2). The gross domestic output before production tax $\left(\mathrm{Z}_{\mathrm{e}}\right)$ from the electricity generation sector is nested by CES function of hydropower electricity generation and other thermal electricity generation (i.e., diesel generation plants, biomass based electricity generation and MSW based electricity generation). The individual technology based electricity generation further comprised of intermediate inputs and factors composition combined in fixed proportion.

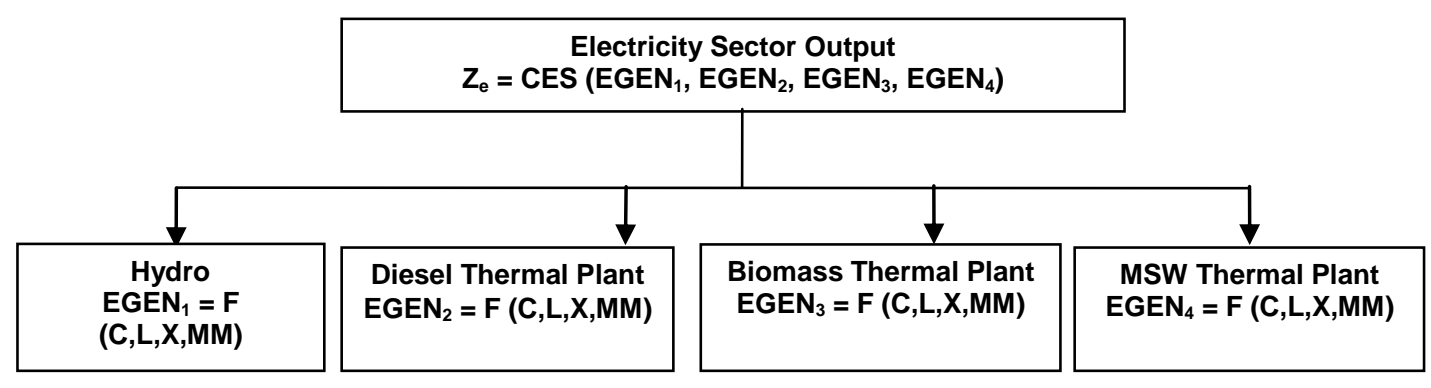

Figure 2: Nested production structure for Electricity Sector

\subsection{Structure of disaggregated land freight transport sector}

In this study, transport sector production function is represented at the level of specific technology based on transport mode (road, rail and ropeway), transport category (truck, pickup, and tractor), fuel type, and motive power generation (internal combustion, electric and hybrid). The detail disaggregation of the freight transport sector is shown in Figure 3. The individual technology based transport demand comprised of fixed ratio intermediate inputs and factors composition. 


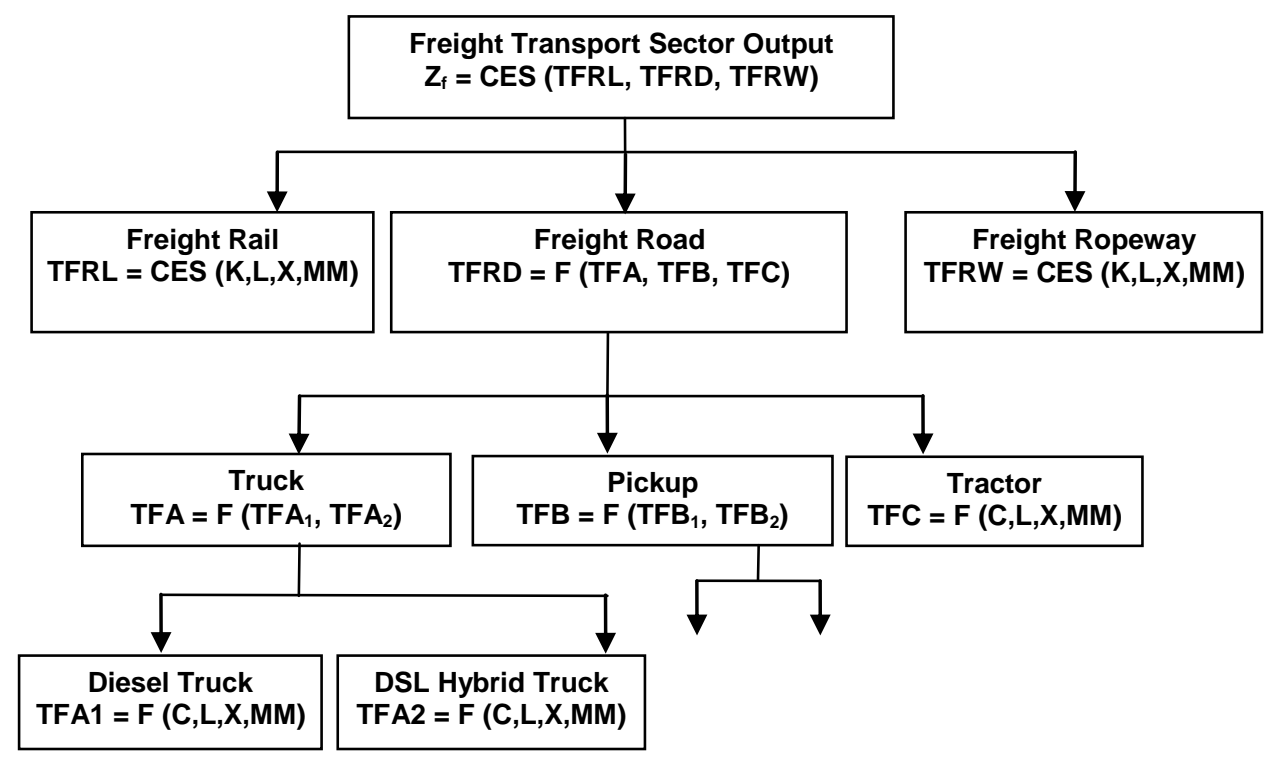

Figure 3: Nested production structure for Land Freight Transport Sector

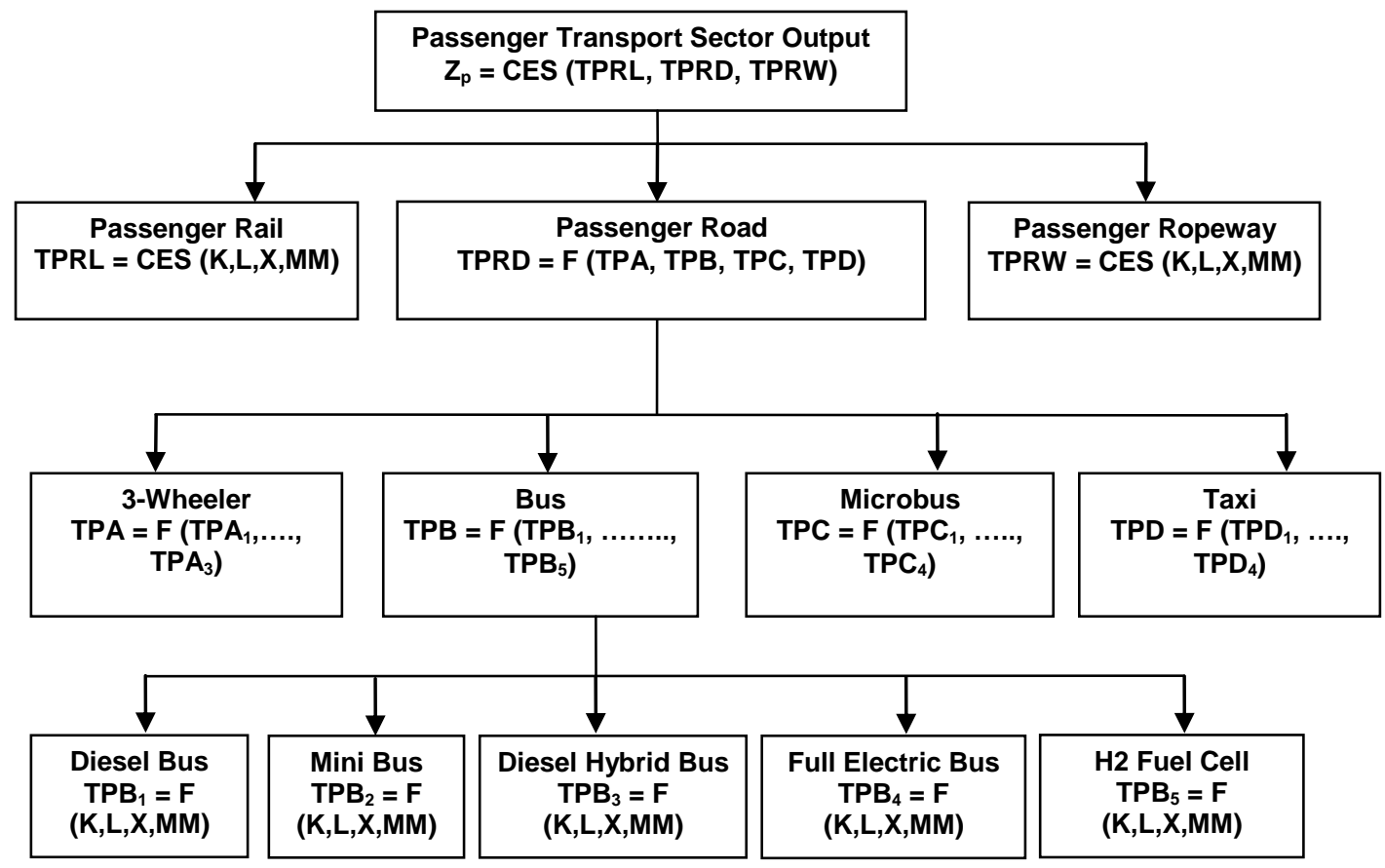

Figure 4: Nested production structure for Land Passenger Transport Sector 


\subsection{Structure of disaggregated land passenger transport sector}

Similar to the land freight transport sector, the production function of land passenger transport is represented with disaggregation of specific technology based on transport mode (road, rail and ropeway), transport category (3-wheeler, bus, microbus and taxi), fuel type, and motive power generation (internal combustion, hybrid and full-electric). The detail disaggregation of the passenger transport sector is given in Figure 4. The individual technology based transport demand further comprised of fixed ratio intermediate inputs and factors composition.

\subsection{Structure of household consumption}

In order to analyze the effects of the transport sector electrification on household consumption and welfare, the household utility is disaggregated into five level nested consumption functions as shown in Figure 5. The household maximize its utility for each level of consumption. At the highest level, total utility function (U) is represented by CES function of aggregated nontransport and aggregated transport consumption ${ }^{1}$. At the second level, the household nontransport consumption (HDNT) consists of energy consumption (HDE) and non-energy consumption (HDNE) nested by CES function. Energy consumption is further consists of electricity (HDEL) and non-electricity fuel composite (HDFS) consumption aggregated by CES function at the third level. In the same level, non-energy consumption is comprises of the individual non-energy consumptions excluding transport consumption. At the final level individual non-electricity fuels are aggregated by using CES function.

Similarly, in the second level, household transport consumption comprises of private transport (TRPR) and purchased transport (TRPU) consumptions which are aggregated by CES consumption function. In the third level private transport is disaggregated into 2-wheeler (TR2W) and car (TRCR) categories of private transport consumption. In the same level, purchased transport is disaggregated into air passenger transport (TAIR) and purchased land passenger transport (TLND). In the fourth level, non-electric fuel (HDFS) consumption consists of nested aggregation of individual fuels (FSi). The specific category of private transport (TR2W and TRCR) consists of CES nested aggregation of different technology based on motive power generation and fuel type (diesel IC, gasoline IC, diesel-hybrid, gasoline-hybrid and full-electric) under the same level. Further in the forth level, purchased land passenger transport (TLND) consists of nested CES consumption function of road passenger (TPRD), ropeway passenger (TPRW) and railway passenger (TPRL) transport modes. In the fifth level, the individual private transport technology comprises of fuel consumption, service provided from the motor vehicles and commercial sectors combined in fixed proportion.

\footnotetext{
${ }^{1}$ Abrell (2010), Paltsev et al. (2004) and Schafer and Jacoby (2005) have also disaggregated transport consumption separate from rest of the other consumption in the household consumption representation.
} 


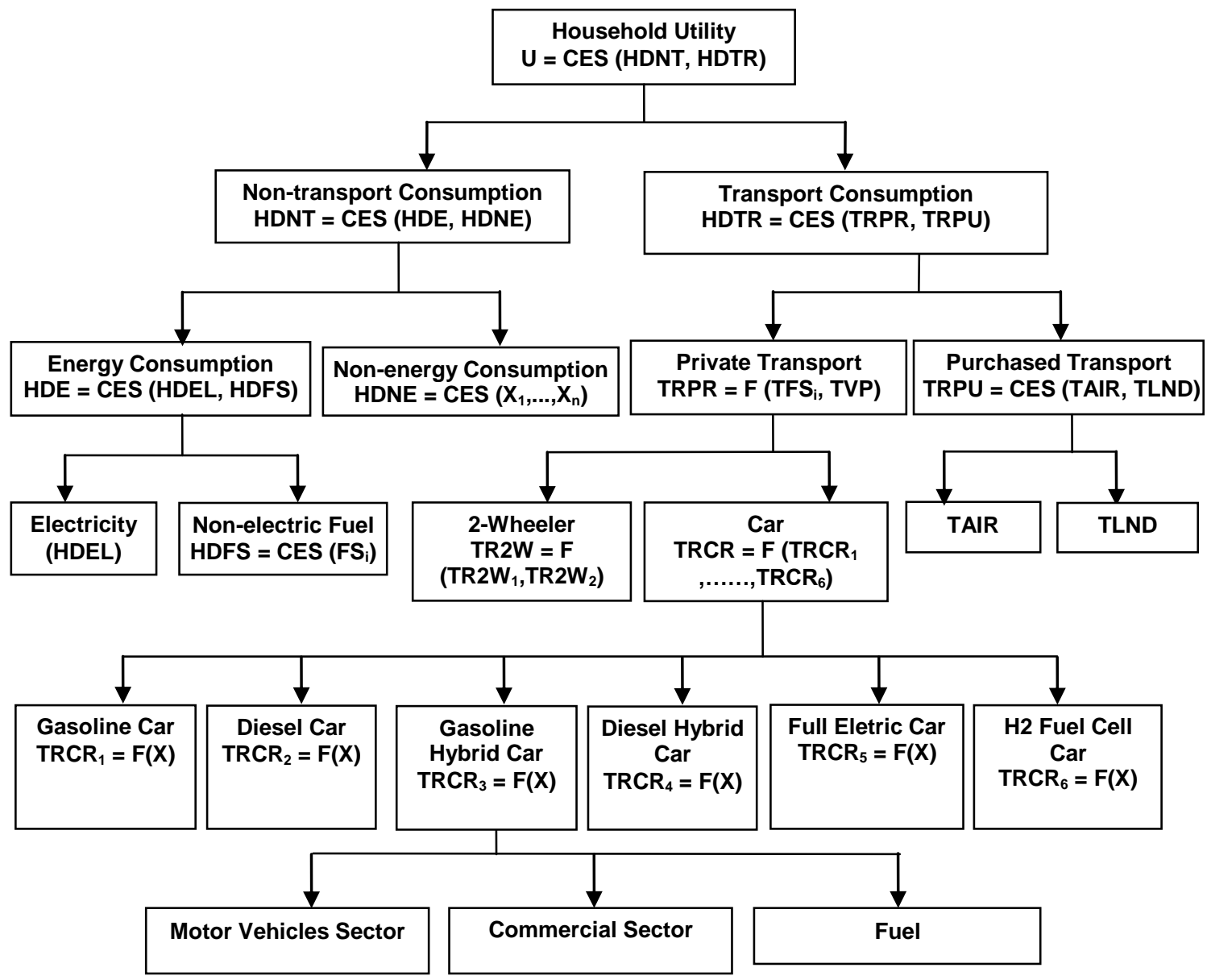

Figure 5: Nested household consumption structure

\subsection{Trade of commodities}

A small-country assumption ([4]) is used in Nepal-TRNSCGE model indicating the production and demand in the national economy will have no effect on the international market price of the commodity.

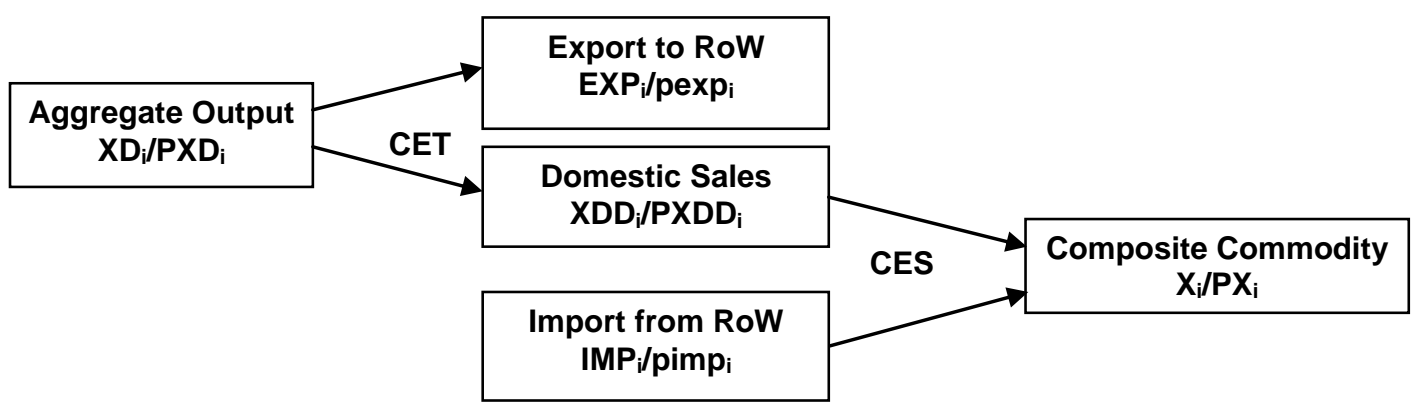

Figure 6: Representation of traded commodities in production and consumption sectors in the NepalTRNSCGE model 
The summarized representation of traded commodities in production and consumption sectors is shown in the Figure 6 . The aggregate domestic produced commodity output $\left(\mathrm{XD}_{\mathrm{c}}\right)$ is consumed by export to RoW $\left(\mathrm{EXP}_{\mathrm{c}}\right)$ and domestic market $\left(\mathrm{XDD}_{\mathrm{c}}\right)$ governed by the constant elasticity of transformation (CET) function. Similarly, the domestic consumers acquire commodity i from import from RoW $\left(\mathrm{IMP}_{\mathrm{c}}\right)$ and domestic production $\left(\mathrm{XDD}_{\mathrm{c}}\right)$ aggregated using the CES function.

\subsection{Social Accounting Matrix of Nepal}

A benchmark SAM of Nepal for the base year 2005 has been constructed for the purpose of this study based on the 2000/01 input-output table [21], national account [29,35] and national energy structure [53]. Table 2 shows the aggregated SAM used in this study.

Following procedure has been followed in the construction of the new SAM for 2005:

a) The input-output structure of 2005 was considered as similar to that of 2000/01 [21]. Following, [20] and [1], every entry in the cells of the domestic intermediate input, noncompetitive imported intermediate input, production tax and import tariff were scaled up in proportion to the change in gross output at constant prices.

b) The commodity wise export and import data were updated using [35] and [17].

c) National account data on, government investment, foreign investment, transfer to ROW from government and household were taken from [29] and [17]. In order to achieve a balance in the income and expenditure of institutions in SAM, the household investment, foreign transfer to government and household were adjusted [1].

d) In order to represent energy sector effectively, electricity, lignite and fuel-wood were considered as separate activity in the production sector. The imported energy resources consisting of diesel, gasoline, kerosene, ATF, industrial grade coal and LPG were represented as individual imported fuel for intermediate input in the production activity and commodity supplied to the domestic market. The sector wise disaggregation of the individual fuel account was done by using energy distribution ratio as reported in the energy balance of Nepal for 2005 [53]. The total cost of traded petroleum products, coal and electricity was estimated using [53], [17] and [34].

e) Electricity is treated as separate commodity which is produced from the four power generation technologies (hydropower, diesel-fired power plant, wood gasification combined cycle power plant, and MSW-based power plant).

f) The land transport sector is disaggregated into land freight and land passenger transport services. Following [44] and [49], the land freight transport service is considered as one of the components of domestic intermediate input, where as the land passenger transport service is considered as a component of household transport service consumption. 
Table 2: Aggregate SAM of Nepal for 2005 (Million Nepalese Rupees)

\begin{tabular}{|c|c|c|c|c|c|c|c|c|c|c|c|}
\hline & \multicolumn{9}{|c|}{ Expenditure } \\
\hline & & & \multicolumn{2}{|c|}{ Production } & \multicolumn{2}{|c|}{ Factors } & \multicolumn{2}{|c|}{ Institutions } & \multirow{2}{*}{$\begin{array}{l}\text { Capital } \\
\text { Account }\end{array}$} & \multirow[b]{2}{*}{$\begin{array}{l}\text { Rest of } \\
\text { World }\end{array}$} & \multirow[b]{2}{*}{ Total } \\
\hline & & & Activities & $\begin{array}{c}\text { Commodi } \\
\text { Ties }\end{array}$ & Labor & Capital & $\begin{array}{c}\text { House } \\
\text { hold }\end{array}$ & Govt. & & & \\
\hline \multirow{9}{*}{ 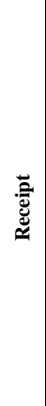 } & \multicolumn{2}{|c|}{ Activities } & & 914,088 & & & & & & & 914,088 \\
\hline & \multicolumn{2}{|c|}{ Commodities } & 258,234 & & & & 458,737 & 60,040 & 187,803 & 85,245 & $1,051,059$ \\
\hline & \multirow{2}{*}{ Factors } & Labor & 299,383 & & & & & & & & 299,383 \\
\hline & & Capital & 270,302 & & & & & & & & 270,302 \\
\hline & \multirow{2}{*}{$\begin{array}{c}\text { Instituti } \\
\text { ons }\end{array}$} & Household & & & 299,383 & 270,302 & & 2,823 & & 51,210 & 623,717 \\
\hline & & Government & 10,222 & 27,840 & & & 10,466 & & & 37,500 & 86,028 \\
\hline & \multicolumn{2}{|c|}{ Capital Account } & & & & & 150,907 & 17,213 & & 19,683 & 187,803 \\
\hline & \multicolumn{2}{|c|}{ Rest of World } & 74,948 & 109,131 & & & 3,606 & 5,953 & & & 193,638 \\
\hline & \multicolumn{2}{|c|}{ Total } & 914,088 & $1,051,059$ & 299,383 & 270,302 & 623,717 & 86,028 & 194,279 & 193,638 & \\
\hline
\end{tabular}

Sources: [17], [21], [29], [34], [35], [53]

\section{Methodology}

The transport sector electrification policy is represented in the model by exogenously introducing different levels of electrified transportation systems in the total transport service demand for the land freight, land passenger public transport services and privately owned transport facilities as obtained from Nepal-MARKAL model [47]. The model is developed by using monetary unit as well as non-monetary units following [41]. 'PJ' is used as the initial unit for the electricity generation sector, 'billion passenger $\mathrm{km}$ ' for land passenger public and private owned transport demand and 'billion ton $\mathrm{km}$ ' for land freight transport demand. Later, all nonmonetary units are converted into the monetary unit at the stage of final commodity supplied to the market by multiplying the physical unit with fixed conversion factor (monetary unit per physical unit). The use of non-monetary unit for demand would facilitate the technology level selection based on per unit cost of service demand in physical unit (non-monetary). The planning horizon of the study is 2005 to 2050 .

The dynamic function equations are used to represent the future total stocks of labor and capital supply. Upper limits on the electricity generation for the non-hydropower electricity generation are set in agreement with the limits set in the Nepal-MARKAL model. An annual energy efficiency improvement (AEEI) factor in the production sectors and energy efficiency improvement (EEI) factor in household end-use energy consumption are assumed to be in the range of 0.002 to 0.009 . The labor productivity growth rate is considered to be in the range of 0.005 to 0.01 . These values are within the range of as used in other studies $[8,37,51,54]$. Emission factors for $\mathrm{CO}_{2}$ emission from carbon intensive fuels are based on [22]. For non- $\mathrm{CO}_{2}$ GHG emissions (i.e., $\mathrm{CH}_{4}$ and $\mathrm{N}_{2} \mathrm{O}$ ), technology specific fuel emission factors are used for electricity generation, land freight transport sector, land passenger transport sector, and private transport based on IPCC (2006). For other sectors which are not disaggregated into the level of technology and for household consumption in the Nepal-TRNSCGE model, emission factors are estimated by using sector specific non- $\mathrm{CO}_{2}$ emission factor for each source estimated by using the outputs of Nepal-MARKAL model under the base case scenario following [41].

The analysis of transport electrification policy is carried out by following procedure: 
a) First of all, the technology wise final transport demands for land freight transport (truck, tractor, pickup, ropeway and railway), land passenger public transport (bus, microbus, 3-wheelers, taxi, ropeway and railway) and private owned transport (car and 2wheelers) in each period are obtained from Nepal-MARKAL model output and are used as exogenous input in the Nepal-TRNSCGE model. The projected land transport service demand for Nepal during 2005 to 2050 is given in Table 3 [47].

b) The technology wise transport service demands in physical unit of the individual land transport services from production sectors and privately owned transports are introduced exogenously in the Nepal-TRNSCGE model.

c) The model is run with exogenously introduced technology wise distribution of transport service demands for the base case and different transport electrification cases.

d) The analysis is carried out by comparison and interpretation of the results from the base case and counterfactual scenarios (transport electrification scenarios) to determine macroeconomic implications in terms of GDP distribution, household welfare, energy intensity and GHG emission intensity.

e) Then effect of foreign direct investment in the policy scenario is studied by exogenously introducing foreign capital consisting of $25 \%, 50 \%$ and $100 \%$ of additional investment required under selected transport electrification scenario as compared to the base case during 2020 to 2050 .

Table 3: Projected land transport service demand during 2005-2050

\begin{tabular}{lcccccc}
\hline Transport Type & $\mathbf{2 0 0 5}$ & $\mathbf{2 0 1 5}$ & $\mathbf{2 0 2 0}$ & $\mathbf{2 0 3 0}$ & $\mathbf{2 0 5 0}$ & $\begin{array}{c}\text { Ratio } \\
\mathbf{2 0 5 0 / 2 0 0 5}\end{array}$ \\
\hline $\begin{array}{l}\text { Land Freight } \\
\text { (billion ton-km) }\end{array}$ & 2.21 & 4.18 & 5.72 & 9.65 & 14.28 & 19.12 \\
\hline $\begin{array}{l}\text { Land Passenger } \\
\text { (billion passenger-km) }\end{array}$ & 20.84 & 44.38 & 62.99 & 111.99 & 170.48 & 231.66 \\
\hline
\end{tabular}

Altogether four scenarios are used for analyzing macroeconomic effects of transport sector electrification as follows:

(i) Base case: In this study the base case (BASE) scenario is defined as the business-asusual case without any transport sector electrification policy being introduced. In order word no electrified mass transport and electric vehicles are allowed to penetrate during the study period. The future labor factor growth is assumed to follow population growth in future. It is assumed that the population growth during 2005 to 2020 would be same as mentioned in [11] and then after it would follow the medium variant growth rate as mentioned in UNPD (2009) during 2020 to 2050. The future total capital factor is determined by the depreciated total capital and new real investment of the previous year. The level of total gross investment was varied through iteration method to maintain the level of energy consumption as close to the one obtained from the NepalMARKAL model analysis. 
(ii) EMT10: a shift of $10 \%$ of the road transport demand to the electric mass transport system from 2020 onwards and all other things remaining the same as in the base case as shown in Figure 7.

(iii) EMT20: a shift of $10 \%$ of the road transport demand to the electric mass transport system in 2020 and gradually increase the shift to $20 \%$ by 2050 .

(iv) EMT30: a shift of $10 \%$ of the road transport demand to the electric mass transport system in 2020 and gradually increase the shift to $30 \%$ by 2050 .

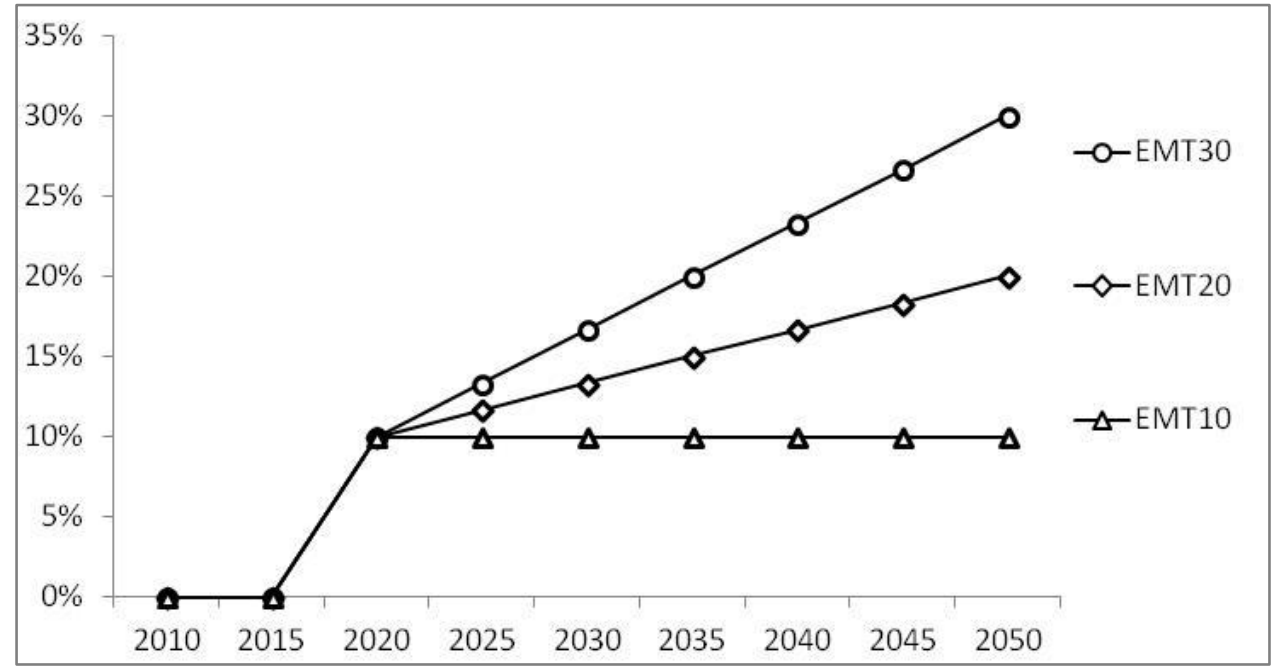

Figure 7: Share of electric transport system in the total road transport demand during 2005 to 2050

In addition, other three scenarios are developed for analyzing the effect of foreign direct investment by exogenously introducing foreign capital consisting of $25 \%, 50 \%$ and $100 \%$ of additional investment required under 30\% transport electrification (EMT30) scenario during 2020 to 2050 .

\section{Analysis of the Base Case Scenario}

Following the procedures as mentioned above, the nominal GDP of Nepal is estimated to grow at an annual compounding growth rate (ACGR) of 7.19\% from NRs. 0.60 trillion in the base year 2005 to NRs. 13.80 trillion by 2050 as shown in Figure 8. The share of consumption demand from household and government, fixed investment demand, export and import of commodities as the percentage of GDP would change during the study periods as shown in Table 4. The consumption demand accounts for the major share (over 76\%) in the national GDP during 2005 to 2050. The contribution of investment demand in GDP lies between $24.7 \%$ to $36.5 \%$ during $2005-2050$. While that of the trade deficit as percentage of GDP is gradually decreasing from $16.2 \%$ in 2005 to $5.0 \%$ by 2050 .

The value of equivalent variation $(\mathrm{EV})$ in income is estimated to increase significantly during 2005-2050 indicating improvements in the national household welfare. This indicates that real income of the national household relative to its income in the base year have increased during the study period. This can also be attributed to the estimated higher growth rates for GDP and private consumption (ACGR of 7.02\% during 2005 to 2050) as compared to the growth rate of 
the population during the study periods (ACGR of $1.48 \%$ during the study period). The exchange rate would initially appreciate but depreciate after 2030 .

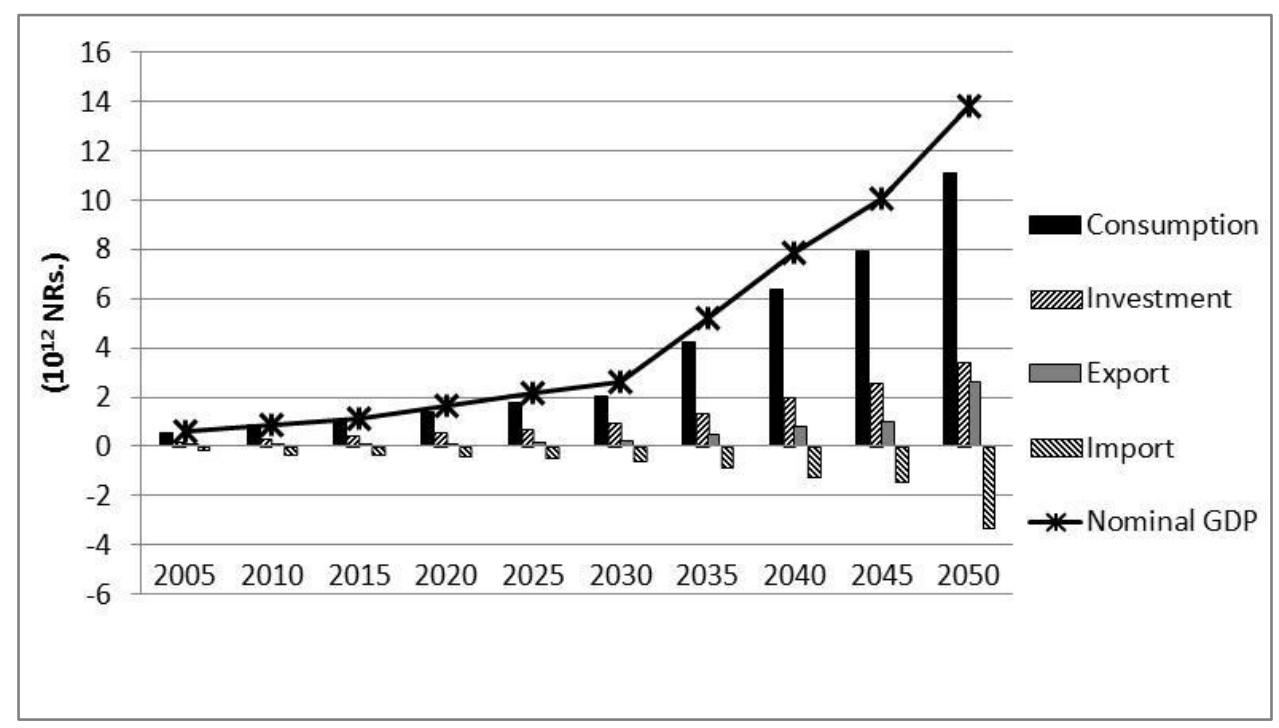

Figure 8: Estimated GDP of Nepal under the base case scenario (BASE) during 2005-2050 (Note: trend line represent Nominal GDP growth path)

Table 4: The estimated macro-economic parameters of Nepal under the base case scenario for selected years

\begin{tabular}{|c|c|c|c|c|c|}
\hline & 2005 & 2020 & 2030 & 2040 & 2050 \\
\hline GDP $\left(10^{12} \mathrm{NRs}\right)$ & 0.61 & 1.64 & 2.64 & 7.88 & 13.80 \\
\hline Consumption ( $\%$ as of GDP) & 85.55 & 86.16 & 76.38 & 80.51 & 80.26 \\
\hline Investment ( $\%$ as of GDP) & 30.65 & 32.78 & 36.49 & 25.07 & 24.75 \\
\hline Exports ( $\%$ as of GDP) & 13.68 & 7.49 & 9.20 & 10.21 & 18.97 \\
\hline Imports (\% as of GDP) & 29.87 & 26.43 & 22.07 & 15.78 & 23.98 \\
\hline Equivalent variation (welfare) ${ }^{a}$ & & 0.05 & 0.42 & 0.89 & 1.09 \\
\hline Exchange Rate $^{\mathrm{b}}$ & 1.00 & 0.78 & 0.72 & 1.33 & 2.78 \\
\hline
\end{tabular}

${ }^{\mathrm{a}}$ Measured in terms of equivalent variation (EV) in income

${ }^{\mathrm{b}}$ Measured in with reference to the base year value as 1 .

Table 5: Energy and emission intensities under the base case during 2000-2050

\begin{tabular}{lccccc}
\hline Sector & 2005 & 2020 & 2030 & 2040 & 2050 \\
\hline Final Energy Consumption (PJ) & 337.12 & 476.02 & 539.43 & 636.16 & 753.13 \\
Total GHG Emission $\left(10^{6}\right.$ ton $)$ & 5.76 & 11.26 & 16.03 & 23.24 & 26.62 \\
Energy intensity $\left(\mathrm{MJ} / 10^{3} 2005 \mathrm{NRs}\right)$ & 554.82 & 292.16 & 206.84 & 78.95 & 52.73 \\
GHG intensity (kg/10 $2005 \mathrm{NRs})$ & 9.47 & 6.91 & 6.15 & 2.88 & 1.86 \\
\hline
\end{tabular}


The study also shows that the country would proceed towards less energy and emission intensive economy in the long run as shown in the Table 5. The energy intensity of GDP would decrease significantly from $555 \mathrm{MJ} / 10^{3} 2005 \mathrm{NRs}$ to $53 \mathrm{MJ} / 10^{3} 2005 \mathrm{NRs}$ during 2005 to 2050 . The electricity intensity of GDP would increase initially and decrease in the later period of the study period. The GHG emission intensity shows decreasing trend but not as fast as energy intensity. This is because the future energy consumption is expected to compose of considerable amount of carbon intensive fuels as cleaner and renewable energy resources are relatively more expensive. Besides some renewable energy resource like fuel wood and municipal solid waste are available in limited amount.

\section{Macroeconomic effects of Transport Sector Electrification}

A number of interesting questions arise: What would be the macro-economic effects of the transport sector electrification in the medium and long term? What would be the effect on the household welfare due to this policy? How would it change the energy intensity and GHG emission intensity of the economy? These issues are discussed in this section for five different scenarios of transport sector electrification considered in the present study.

\subsection{Effects on Macroeconomic and Welfare Indicators}

The study shows that an electrification of transport sectors would have positive effects on the national economy with increase in the GDP of the country as compared to the base case. This change in the GDP is attributed to the change in the GDP distribution due to the reallocation of the factors of production, intermediate inputs among all domestic production sectors from the supply side and change in the level of consumption and net trade in demand side. The cumulative undiscounted real GDP at 2005 price during 2005 to 2050 would be 197.4 trillion in the base case (Figure 9). There would be increase in the cumulative real GDP by $2.8 \%$ under EMT10, 2.6\% under EMT20, and 3.1\% under EMT30 as compared to the base case. In case of EMT20+EV10 and EMT20+EV15, the cumulative real GDP would increase by $2.9 \%$ and $2.5 \%$ respectively. This result is in agreement with other related studies by [18] and [13]. Gilbert and Banik (2010) mentioned increase in GDP as investment flows in international land transport infrastructure in case of South Asian countries (Pakistan, Bangladesh, India, Sri Lanka and Nepal). Chuanyi et al. (2010) found there would be increase in GDP when the scale of investment in energy sectors is increased in case of Shaanxi Province of China.

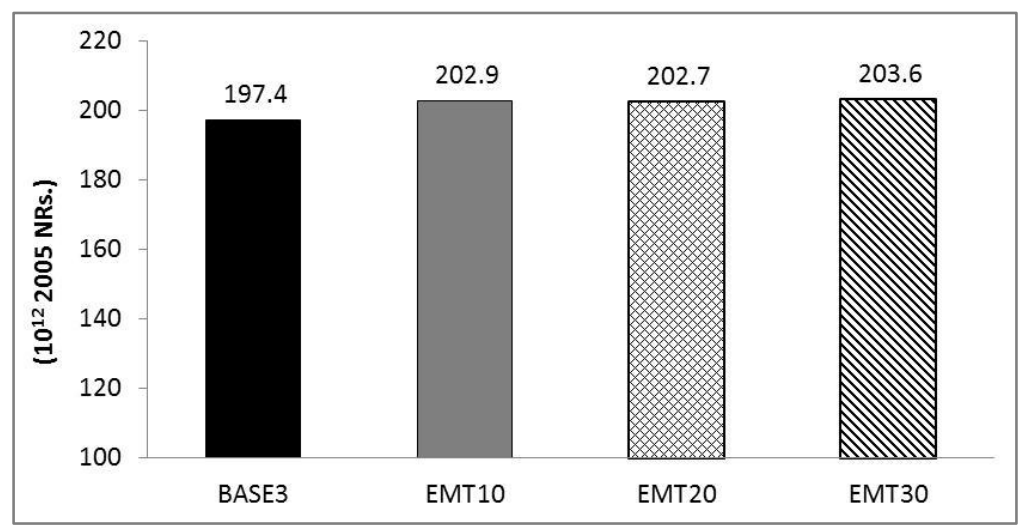

Figure 9: Estimated cumulative undiscounted real GDP at 2005 price during 2005-2050 


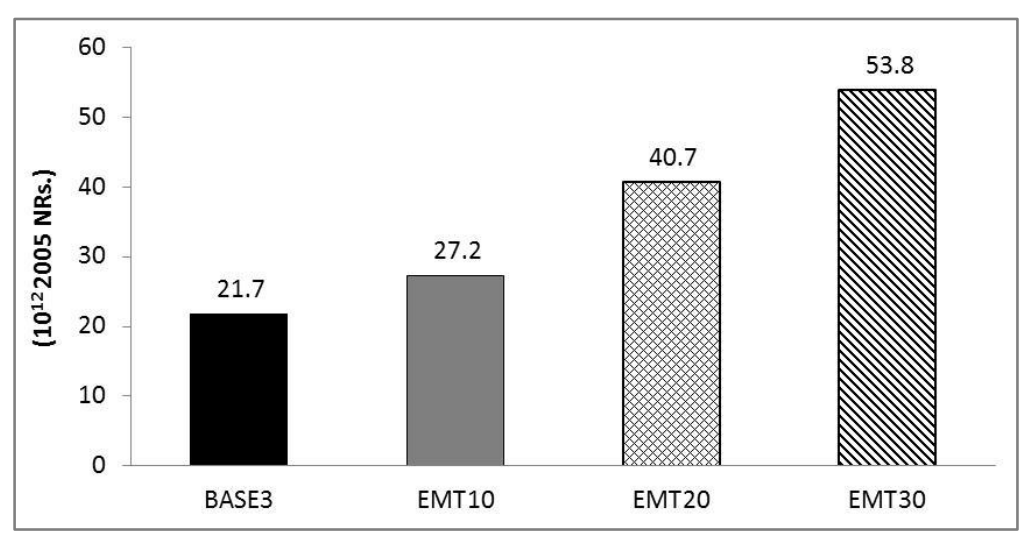

Figure 10: Estimated cumulative household welfare during 2005-2050

The cumulative household welfare during 2005 - 2050 would increase under all the transport electrification scenarios as shown in Figure 10. The increase in the household welfare in terms of an increase in the value of the cumulative undiscounted equivalent variation in income during 2005-2050 ranges from 25.3\% under EMT10 to $147.9 \%$ under EMT30 as compared to the base case. Gilbert and Banik (2010) mentions increase in household welfare as investment flows in international land transport infrastructure in case of five South Asian countries.

\subsection{Effects on Energy Consumption and Environment}

The value of average energy intensity of GDP would be decreased by $3.8 \%$ under EMT10, $4.1 \%$ under EMT20 and 3.1\% under EMT30 (Table 6). The average GHG intensity would be decreased by $4.7 \%$ under EMT10, 5.3\% under EMT20 and 7.1\% under EMT30 (Table 6). This indicates that the transport electrification policies could be one of the effective tools to pursue low carbon development path in the country.

Table 6: Estimated final energy consumption and GHG emission during 2005-2050

\begin{tabular}{lcccc}
\hline Parameter & BASE & EMT10 & EMT20 & EMT30 \\
\hline Cumulative Final Energy Cosnumption (PJ) & 24,120 & 23,534 & 21,227 & 22,659 \\
Cumulative GHG emission $\left(10^{6}\right.$ tons) & 731.75 & 699.77 & 608.84 & 592.89 \\
Energy intensity (MJ/10 $\left.{ }^{3} \mathrm{NRs}\right)$ & 237.23 & 228.17 & 227.60 & 229.96 \\
GHG intensity (kg/103NRs) & 6.12 & 5.83 & 5.79 & 5.68 \\
\hline
\end{tabular}

\section{Effects of Foreign Direct Investment}

The role of foreign direct investment is very crucial in the economic development of developing country, citing their limited domestic possession and access to the much needed capital. The electrification of transport sector is expected to required significant amount of capital investment mostly in the transport and electricity sectors. However, there might be negative effects associated with the flow of foreign investment in the national economy $[3,5,16]$. Ahmed and O'Donoghue (2010) analysed the effects of foreign investment growth in the form of increase in the level of exogenous foreign saving. This would however does not reflect the actual flow of 
foreign direct investment in the national economy as total capital accumulation is owned by the national household and there is no direct role of foreign institution in the ownership of total capital formation in the national CGE model. Besides, additional capital accumulation from the increase in the foreign saving comes at the cost of forced increment in the negative trade balance (i.e., increase in import and decrease in export to compensate additional amount of foreign saving). In order to investigate effects of FDI more accurately, a global economic model with the country under study as sub-region is required with provision of substitution between domestic capital and foreign capital. As the present study use national economic model without global market interaction, endogenous introduction of FDI is not possible. Here, effect of FDI is investigated indirectly by exogenously introducing new additional capital which is owned by the foreign institution. Government would charge income tax on the earning from FDI to the foreign institution.

Here three scenarios are considered for analyzing the effects of FDI under selected transport electrification scenario, i.e., EMT30, as following:

(i) Introduction of FDI capital equal to $25 \%$ of the additional investment required in the transport and electricity sectors under EMT30 as compared to the base case (Here after "FDI25").

(ii) An addition of FDI equal to 50\% of the additional investment required under EMT30 as compared to the base case (Here after "FDI50").

(iii) Introduction of FDI equal to $100 \%$ of the increase in the additioanl investment required under EMT30 (Here after "FDI100").

\subsection{Effects on Macroeconomic Indicators}

The study shows that increasing the level of FDI would increase the cumulative undiscounted real GDP at 2005 price by 5.6\% under FDI25, 9.8\% under FDI50 and 11.0\% under FDI100 as compared to EMT30 without FDI during 2005 to 2050 (Figure 11). This is mostly due to the increase in the value of investment from additional supply of capital from FDI. The cumulative household welfare during the study period would decrease under all the FDI scenarios due to the additional supply of capital from abroad resulting changes in the domestic price of factors of production and commodities as shown in Figure 12. This indicates increasing the role of FDI in the economy may not necessarily improve the welfare of the national household.

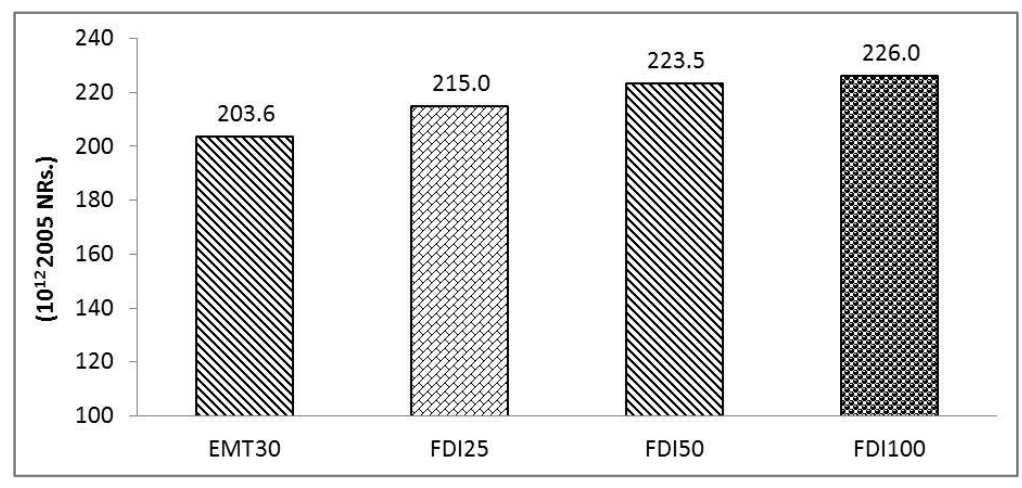

Figure 11: Estimated cumulative undiscounted real GDP at 2005 price during 2005-2050 


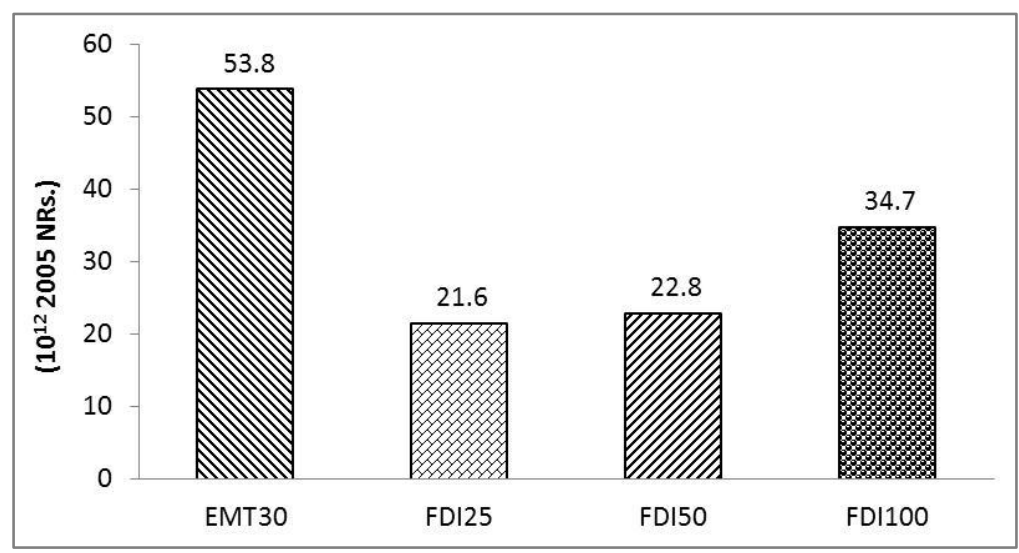

Figure 12: Estimated cumulative household welfare during 2005-2050

\subsection{Effects on the Energy Consumption and Environment}

The study shows that foreign investment would result in a decrease in energy and GHG emission intensities of GDP under all FDI scenarios as compared to the base case. The average energy intensity of GDP during 2005 to 2050 would be $230.7 \mathrm{MJ} / 10^{3} 2005$ NRs under EMT30 without FDI (Table 7). The value of average energy intensity of GDP would be decreased by $3.7 \%$ under FDI25, 3.3\% under FDI50 and 1.9\% under FDI100. Similarly, the average GHG intensity of GDP during the study period would be $5702.6 \mathrm{~kg} \mathrm{CO}_{2} \mathrm{e} / 10^{3} 2005$ NRs under EMT30 without FDI (Table 7). The average GHG intensity would be decreased by $4.3 \%$ and $1.0 \%$ under FDI25 and FDI50, where as it would increase by $2.7 \%$ under FDI100.

Table 7: Estimated final energy consumption and GHG emission during 2005-2050

\begin{tabular}{lcccc}
\hline Parameter & EMT30 & FDI25 & FDI50 & FDI100 \\
\hline Cumulative Final Energy Cosnumption (PJ) & 24,120 & 23,534 & 21,227 & 22,659 \\
Cumulative GHG emission $\left(10^{6}\right.$ tons) & 592.89 & 553.69 & 644.06 & 706.62 \\
Energy intensity (MJ/10 $\left.{ }^{3} \mathrm{NRs}\right)$ & 229.96 & 222.11 & 223.04 & 226.27 \\
GHG intensity (kg/103NRs) & 5.68 & 5.46 & 5.65 & 5.86 \\
\hline
\end{tabular}

\section{Conclusion and Policy Implications}

The study indicates that Nepal would benefit from the implementation of the transport sector electrification in the long run with an increase in GDP and household welfare in all the transport electrification scenarios. Besides, the transport electrification would promote energy efficiency improvement and low carbon economy with a significant reduction in the energy and greenhouse gas intensities of GDP. This highlights the importance of the transport sector electrification as one of the desirable options in achieving the low carbon development path in the country.

Altogether three transport electrification scenarios were considered consisting of a shift of $10 \%$ of the road transport demand to the electric mass transport system in 2020 and maintain at $10 \%$ (EMT10) till 2050, or gradually increase the shift to 20\% (EMT20) and 30\% (EMT30) by 2050. 
The study shows that the cumulative undiscounted real GDP at 2005 price during the study period would increase in the range of $2.6 \%$ under EMT20 to 3.1\% under EMT30 as compared to the base case. The household welfare would increase under all the transport electrification scenarios with an increase in the value of the cumulative undiscounted equivalent variation in income in the range of $25.3 \%$ under EMT10 to $147.9 \%$ under EMT30 during 2005-2050.

The study shows that the national economy shifts towards the energy efficient path under the transport electrification policy with a decrease in energy intensity of GDP. The average energy intensity of GDP during 2005 to 2050 would be $237.2 \mathrm{MJ} / 10^{3} 2005 \mathrm{NRs}$ under the base case. The value of the average energy intensity would be decreased in the range of 3.1\% under EMT30 to $4.1 \%$ under EMT20 as compared to the base case.

The study also indicates that, the transport electrification policy would help the country to pursue a low carbon development path in the long run thus supporting the effective implementation of national climate change policy 2010. The average GHG intensity during the study period would be $6116.5 \mathrm{~kg} \mathrm{CO}_{2} \mathrm{e} / 10^{3} 2005 \mathrm{NRs}$ under the base case. The average GHG intensity would be decreased in the range of $4.7 \%$ under EMT10 to $7.1 \%$ under EMT30 as compared to the base case value.

Interestingly, the foreign direct investment would further increase GDP but would decrease household welfare.

In the backstop of the above mentioned results, this study comes out with the following recommendations for the policy makers and related stakeholders;

- The national policy makers should give special emphasis on the implementation of transport electrification program citing the multi-faceted benefits of its implementation. There is a need for studying the elaborate inter-relationship among the policies related to energy, climate change and transport so as to develop the effective and sustainable policy in an integrated framework on the long run.

- The government should create an enabling environment by developing and implementing effective policies to attract Foreign Direct Investment (FDI) as it would increase GDP. However, there is the need for study of the additional mechanism to improve household welfare under increasing role of FDI (such as transferring the tax revenue on FDI to households).

- International communities should support the clean and renewable energy based transport sector electrification program in the developing country through the financial support (with allocation of different GHG mitigation funds under international cooperation) and proper technology transfer to help mitigate global green house gas emissions.

- Successful implementation of the transport sector electrification and realization of its multi-faceted benefits depends on many factors. This study is focused on the economywide effects in terms of GDP, household welfare, energy intensity, GHG emission intensity only. Further studies on the transport electrification policy can be done in the issues not covered in this study, such as; implications of incorporating different national and international financing mechanisms; effects of integrating transport electrification policy with other policies; development of global model incorporating the country under study as a sub-region for better understanding of effects of foreign direct investment etc. 


\section{References}

[1] Acharya, S. (2010). Potential impacts of the devaluation of Nepalese currency: A general equilibrium approach, Economic Systems, 34, 413-436.

[2] Acharya, S., and Cohen, S. (2008). Trade liberalization and household welfare in Nepal, Journal of Policy Modeling, 30, 1057-1060.

[3] Ahmed, V. and O'Donoghue, C. (2010). External Shocks in a Small Open Economy: A CGE Microsimulation Analysis, The Lahore Journal of Economics $15: 1$, 45-90.

[4] Armington, P. S. (1969). A Theory of Demand for Products Distinguished by Place of Production, IMF Staff Papers, 16, 159-178.

[5] Barry, M. P. (2009). Foreign Direct Investments in central Asian Energy: A CGE Model, Eurasian Journal of Business and Economics, 2(3), 35-54.

[6] Benjamin, N. C., Devarajan, S., Weiner, R. J. (1989). The Dutch Disease in a Developing Country: Oil Revenues in Cameroon, Journal of Development Economics, 30, 71-91.

[7] Bhattarai, K. R., (1996). Financial Deepening and Economic Development in Nepal: A Forward Looking CGE Model with Financial Intermediation, Ph.D. Dissertation, Department of Economics, Northeastern University, Boston, Massachusetts.

[8] Brenkert, A.L., Sands, R. D., Kim, S. H., Pitcher, H. M. (2004). Model documentation: the second generation model, Pacific Northwest National Laboratory Report 14256, (http://www.globalchange.umd.edu/models/sgm/; accessed on 28 June 2009).

[9] Buehrer, T., di Mauro, F. (1993). A Computable General Equilibrium Model of Nepal, Report No. 60 , Asian Development Bank, Manila.

[10] Burfisher, M. E. (2011). Introduction to Computable General Equilibrium Models, Cambridge University Press, New York.

[11] Central Bureau of Statistics, CBS, (2003). Population Projections for Nepal 2001-2021, National Planning Commission Secretariats, GoN, Kathmandu.

[12] Chuanyi, L. (2009). Effects of investment growth in energy sectors of western areas on local economy and emissions: Case of Shaanxi Province of China based on a CGE model, International Journal of Energy Sector Management, 3 (1), 29-49.

[13] Chuanyi, L., Xiliang, Z., and Jiankun, H. (2010). A CGE analysis to study the impacts of energy investment on economic growth and carbon dioxide emission: A case of Shaanxi Province in western China, Energy, 35 (11), 4319-4327.

[14] Dai, H., Masui, T., Matsuoka, Y., and Fujimori, S. (2011). Assessment of China's climate commitment and non-fossil energy plan towards 2020 using hybrid AIM/CGE model, Energy Policy, 39, 2875-2887.

[15] Devarajan, S., Lewis, J. D., and Robinson, S. (1993). External shocks, purchasing power parity and the equilibrium real exchange rate, World Bank Economic Review, 7, 45-63.

[16] Dhungel, H. (1996). Macroeconomic adjustments to large energy investments in a small controlled open economy: A policy analysis of hydropower development in Paraguay, PhD Dissertation, University of Pennsylvania, Pennsylvania.

[17] Federation of Nepalese Chambers of Commerce and Industry, FNCCI (2006). Nepal and the World: A Statistical Profile, Kathmandu.

[18] Gilbert, J., and Banik, N. (2010). Socioeconomic impacts of Cross-Border Transport Infrastructure Development in South Asia, ADBI Working paper Series No. 211, Tokyo: Asian Development Bank Institute. (http://www.adbi.org/working-paper/2010/04/14/3655.socioeconomic.transport.infrastructure/; accessed on 20 June 2010). 
[19] Gyawali, D., Dixit, A., and Upadhya, M. (2004). Ropeways in Nepal, Nepal Water Conservation Foundation (NWCS), Kathmandu.

[20] Hosoe, N., Gasawa, K., and Hashimoto, H. (2010). Textbook of Computable General Equilibrium Modeling: Programming and Simulations, Palgrave, Macmillan, Hampshire.

[21] Institute for Policy Research and Development, IRPAD (2007). GTAP Compatible Input Output (I/O) Table and Social Accounting Matrix (SAM) for Nepal, Final Report, Submitted to Enhancing Nepal's Trade-Related Capacity, UNDP, Kathmandu.

[22] Intergovernmental Panel on Climate Change, IPCC (2006). IPCC Guidelines for National Greenhouse Gas Inventories, Institute for Global Environmental Strategies, Japan.

[23] Jacoby, H. D., Reilly, J. M., McFarland, J. R., and Paltsev, S. (2006). Technology and technical change in the MIT EPPA model, Energy Economics, (Special Issue: Technological change in climate policy analysis), 28, 610-631.

[24] Kim, E., and Hewings G. J. D. (2003). An Application of Integrated Transport Network-Multiregional CGE Model II: Calibration of Network Effects of Highway, Paper presented at the 42nd Southern Regional Science Association in Louisville, KY, April 10-12, 2003, (http://www.real.illinois.edu/dpaper/03/03-t-24.pdf; accessed on 28 June 2009).

[25] Kojo, N. C. (2005). Bhutan Power Exports and Dutch Disease, Centre for Bhutan Studies: Monographs. (http://www.asia-studies.com/2bhutanmono.html; accessed on 28 June 2010).

[26] Kyophilavong, P., and Toyoda, T. (2008). Foreign capital inflows in the natural resource sectors: Impacts on the Lao economy, Paper presented at The Future of Economic Integration in Asia Conference, 20-21 Nov 2008, Bangkok, Thailand.

[27] Ministry of Energy, MOE (2010). Twenty-Year Hydropower Development Plan 2010-2030, Twenty-Year Hydropower Development Plan Implementation Task Force, GoN, Kathmandu.

[28] Ministry of Environment, MOEV (2010). Climate Change Policy 2010, GoN, Kathmandu.

[29] Ministry of Finance, MOF (2007). Economic Survey Fiscal Year 2006/07, GoN, Kathmandu.

[30] Ministry of Finance, MOF (2010). Economic Survey Fiscal Year 2009/10, GoN, Kathmandu.

[31] Ministry of Water Resource, MOWR (2009). Ten-Year Hydropower Development Plan 2010-2020, Part 1: Main Report, Ten Year Hydropower Development Plan Implementation Task Force, GoN, Kathmandu.

[32] Nakata, T., Silva, D., and Rodionov, M. (2011). Application of energy system models for designing a lowcarbon society, Progress in Energy and Combustion Science, 37, 462-502.

[33] National Environmental and Scientific Services, NESS (2003). Analysis of HMG Policies and Regulations affecting Electric Vehicles, Final report, Kathmandu.

[34] Nepal Electricity Authority, NEA (2006). Nepal Electricity Authority Fiscal Year 2005/06, AYear in Review, Kathmandu.

[35] Nepal Rastra Bank, NRB (2007). Economic Report 2006/07, Kathmandu.

[36] Osmani, S. R., Bajracharya, B. B., Tenzing, S., and Wangyal, T. (2007). Annex 5, Hydropower and Dutch Diesease, In Macroeconomics of Poverty Reduction: The case study of Bhutan, $2^{\text {nd }}$ Edition, A report prepared for UNDP under its regional project on the 'Macroeconomics of Poverty Reduction'. UNDP Regional Centre in Colombo. (http://www.undp.org.bt/assets/files/publication/Macroeco_cs_for_Bhutan.pdf; accessed on 20 Nov 2010).

[37] Paltsev, S., Reilly, J. M., Jacoby, H.D., Eckaus, R.S., McFarland, J., Sarofim, M., Asadoorian, M., and Babiker, M. (2005). The MIT Emissions Prediction and Policy Analysis (EPPA) Model: version 4, Report No.125, MIT Joint Program on the Science and Policy of Global Change. 
[38] Paltsev, S., Viguir, L., Babiker, M., Reilly, J., and Tay, K. H. (2004). Disaggregating Household Transport in the MIT-EPPA Model, Techinical Note No.5, MIT Joint Program on the Science and Policy of Global Change.

[39] RITES Ltd. and SILT Consultants, RITES/SILT (2010). Feasibility Study of Mechi-Mahakali and Pokhara-Kathmandu Electric Railway, Submitted to Ministry of Physical Planning and Works (MOPPW), GoN, Kathmandu.

[40] Rosenthal, R. E. (2011). GAMS - A User's Guide, Washington, D.C., GAMS Development Corporation.

[41] Sands, R., and Fawcett, A. (2005). The Second Generation Model: Data, Parameters, and Implementation, Prepared for the United States Environmental Protection Agency.

[42] Sapkota, P. P., and Cockburn, J. (2008). Trade Liberalization and Poverty in Nepal: An Applied General Equilibrium Analysis, Poverty and Economic Policy Network, MPIA Working Paper 2008-13.

[43] Sapkota, P. R., and Sharma, R. K. (1998). A Computable General Equilibrium Model of the Nepalese Economy. Paper presented at the Micro Impacts of Macroeconomic and Adjustment Policies (MIMAP), Third Annual Meeting, 2-6 Nov 1998, Kathmandu. (http://www.idrc.ca/uploads/userS/10282122230mimap56.pdf; accessed on 8 June 2008).

[44] Schafer, A., and Jacoby, H. D. (2005). Technology detail in a multisector CGE model: transport under climate policy, Energy Economics, 27, 1-24.

[45] Shakya, S. R. (2012). Analysis of Low Carbon Development Strategies: Role of Transport Sector Electrification and Carbon Tax in Nepal, PhD Dissertation, Asian Institute of Technology, Thailand.

[46] Shakya, S. R., Kumar, S., and Shrestha, R. M. (2012). Co-benefits of a carbon tax in Nepal, Mitigation and Adaptation Strategies for Global Change, 17 (1), 77-101.

[47] Shakya, S.R., and Shrestha, R. M. (2011). Transport sector electrification in a hydropower resource rich developing country: energy security, environmental and climate change co-benefits, Energy Sustainable Development, 15, 147-159.

[48] Shrestha, R. M., and Shakya, S. R. (2012). Benefits of low carbon development in a developing country: Case of Nepal, Energy Economics, doi:10.1016/j.eneco. 2012.03.014.

[49] Siddiqui, R. (2007). Quantifying the impacts of Development of Transport sector in Pakistan, The Pakistan Development Review, 46(4), 779-802.

[50] Warr, P. (2006). The Gregory Thesis Visits the Tropics, The Economic Record, 82 (257), 177-194.

[51] Watcharejyothin, M. (2010). Analysis of Economic and Environmental Implications for Thailand of Integrated Energy Resource Development in Selected Greater Mekong Subregion Countries, PhD Dissertation, Asian Institute of Technology, Thailand.

[52] Water and Energy Commission Secretariat, WECS (2005). National Water Plan 2005, Ministry of Water Resources, GoN, Kathmandu.

[53] Water and Energy Commission Secretariat, WECS (2006). Energy Synopsis Report 2006, Ministry of Water Resources, GoN, Kathmandu.

[54] Webster, M., Paltsev, S., and Reilly, J. (2008). Autonomous efficiency improvement or income elasticity of energy demand: Does it matter?, Energy Economics, 30, 2785-2798. 